\title{
Dissolution-Induced Nanowire Synthesis on Hot-Dip Galvanized Surface in Supercritical Carbon Dioxide
}

\author{
Aaretti Kaleva ${ }^{1, *}$ (D), Ville Saarimaa ${ }^{2}$, Saara Heinonen ${ }^{1}$, Juha-Pekka Nikkanen ${ }^{1}$, \\ Antti Markkula ${ }^{3}$, Pasi Väisänen ${ }^{3}$ and Erkki Levänen ${ }^{1}$ \\ 1 Laboratory of Materials Science, Tampere University of Technology, P.O. Box 589, FI-33101 Tampere, Finland; \\ saara.heinonen@tut.fi (S.H.); juha-pekka.nikkanen@tut.fi (J.-P.N.); erkki.levanen@tut.fi (E.L.) \\ 2 Top Analytica Oy, Ruukinkatu 4, FI-20540 Turku, Finland; ville.saarimaa@topanalytica.com \\ 3 SSAB Europe Oy, Harvialantie 420, FI-13300 Hämeenlinna, Finland; antti.markkula@ssab.com (A.M.); \\ pasi.vaisanen@ssab.com (P.V.) \\ * Correspondence: aaretti.kaleva@tut.fi; Tel.: +358-50-447-8715
}

Received: 7 June 2017; Accepted: 7 July 2017; Published: 11 July 2017

\begin{abstract}
In this study, we demonstrate a rapid treatment method for producing a needle-like nanowire structure on a hot-dip galvanized sheet at a temperature of $50{ }^{\circ} \mathrm{C}$. The processing method involved only supercritical carbon dioxide and water to induce a reaction on the zinc surface, which resulted in growth of zinc hydroxycarbonate nanowires into flower-like shapes. This artificial patina nanostructure predicts high surface area and offers interesting opportunities for its use in industrial high-end applications. The nanowires can significantly improve paint adhesion and promote electrochemical stability for organic coatings, or be converted to $\mathrm{ZnO}$ nanostructures by calcining to be used in various semiconductor applications.
\end{abstract}

Keywords: zinc hydroxycarbonate; nanowire; supercritical carbon dioxide

\section{Introduction}

Hot-dip galvanized (HDG) coatings are widely used in automotive and construction industries. These zinc coatings are most often the outermost material surfaces, which is why they require sufficient corrosion protection and good aesthetics [1]. Painting is the most common method for improving the aforementioned properties. However, the galvanized surface usually needs additional surface modification before painting, e.g., chemical pretreatment, to provide satisfactory adhesion to the substrate [2]. Weathering of a HDG surface means deliberately corroding the surface to produce a patina layer that contains dissolution products of zinc. This patina layer hinders the corrosion rate of the material and enhances paint adhesion [3-5]. In atmospheric corrosion, formation of the patina layer on HDG coating starts by zinc reacting with oxygen from air producing zinc oxide $(\mathrm{ZnO})$. Another initial corrosion product is zinc hydroxide $\left(\mathrm{Zn}(\mathrm{OH})_{2}\right)$, which forms when moisture is present. Subsequently, $\mathrm{ZnO}$ and $\mathrm{Zn}(\mathrm{OH})_{2}$ then react over time with carbon dioxide $\left(\mathrm{CO}_{2}\right)$ forming zinc hydroxycarbonates. After several years of exposure to the atmosphere when no other contaminants are present, the patina layer consists mostly of a type of zinc hydroxycarbonate called hydrozincite $\left(\mathrm{Zn}_{5}\left(\mathrm{CO}_{3}\right)_{2}(\mathrm{OH})_{6}\right)[1,6,7]$. The formed patina enhances paint adhesion by promoting chemical bonding and increasing the roughness of the HDG surface, thus creating anchorage points [5,8]. Waiting for the natural patina to form on HDG is used as a pretreatment before coating the surface to provide better adhesion properties [4]. A disadvantage of the traditional weathering process is that the formation of a fully developed patina layer can take from eight months to two years' time for it to be ready for painting [4]. Consequently, there may be a great interest in industry for the possibility to produce an artificial patina of zinc using a fast and versatile method described in our study. 
According to the literature, zinc hydroxycarbonates with similar composition to those corrosion products found in naturally forming patinas are possible to be transformed into $\mathrm{ZnO}$ nanostructures simply by calcination $[9,10]$. This opens other interesting applications for our method to alter zinc surfaces using supercritical carbon dioxide $\left(\mathrm{scCO}_{2}\right)$, i.e., the possibility to produce photocatalytic nanostructured $\mathrm{ZnO}$. The $\mathrm{scCO}_{2}$ treatment is fast and uses no harmful chemicals compared to conventional hydrothermal synthesis techniques commonly used for $\mathrm{ZnO}$ nanowire synthesis [11]. These nanostructures of zinc oxide have been used in high-end technological applications such as dye-sensitized solar cells [12-14], piezoelectrics [15] and different types of sensors [16,17]. Furthermore, similar nanowire structures might be used in flexible energy storage systems, supercapacitors, solar and hybrid devices [18-23].

Processing with $\mathrm{scCO}_{2}$ has been of great interest in materials research because of its green processing properties and wide range of applicability to various processes. It is used to produce many nanostructures, including nanowires, using different kinds of approaches for the nanostructure synthesis [24-27]. The corrosive behaviour of $\mathrm{scCO}_{2}$ on metals has been studied previously. When $\mathrm{scCO}_{2}$ and water $\left(\mathrm{H}_{2} \mathrm{O}\right)$ are in contact with steel, they react together by forming a compact and protective iron carbonate layer on the steel surface $[28,29]$.

This study presents a rapid and an environmentally friendly method utilizing $\mathrm{scCO}_{2}$ for producing an artificial patina layer on a HDG surface. This $\mathrm{scCO}_{2}$ treatment utilizes only two simple reactants: $\mathrm{CO}_{2}$ and $\mathrm{H}_{2} \mathrm{O}$.

\section{Results and Discussion}

\subsection{SEM Imaging and EDS Analysis}

We can see a significant change in the surface structure between an untreated HDG surface (Figure 1a) and the $\mathrm{scCO}_{2}$-treated sample (Figure 1b). The $\mathrm{scCO}_{2}$ treatment produced thin and long nanowires. The nanowires grow mostly straight from the surface but a few seem to have curved towards the tip of the nanowire. Minor branching of the nanowires can be seen as well. The nanowires seem to grow in many angles from single nucleation points. These nucleation points may be caused by pitting type corrosion. In these conditions, the local zinc corrosion around the pits create favourable conditions for nanowire growth as previously suggested in a study by Miles and Mattia [9]. The growth angle from the nucleation points vary from more perpendicular to almost parallel to the surface. Consequently, the overall nanowire growth results in formation of flower-like shapes. Structures with similar morphology and composition have been formed on zinc in previous studies where zinc surface was anodized in the presence of carbonate-containing electrolytes $[9,10]$. The underlying substrate surface can be seen through the nanowires, which indicates that the surface is not completely covered by the structure.

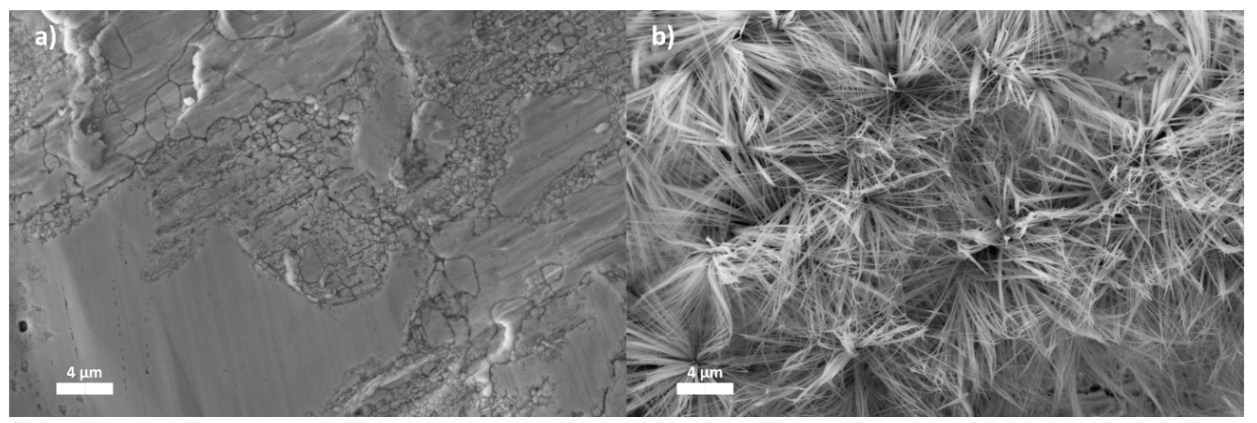

Figure 1. SEM images of rolled hot-dip galvanized (HDG) surface (a) and $\mathrm{scCO}_{2}$-treated surface (b).

The energy dispersive spectrometer (EDS) results show that on the reference surface (without the $\mathrm{scCO}_{2}$ treatment), the elemental composition was: 8.0 at $\%$ oxygen, 2.2 at $\%$ aluminum and 89.8 at $\%$ 
zinc. The nanowire structure contained 15.9 at \% carbon, 62.9 at \% oxygen, 0.1 at \% aluminum and 21.1 at \% zinc. The amounts of carbon and oxygen present in the nanowire structure could indicate the presence of zinc hydroxycarbonate. The EDS analysis also shows that both the reference zinc surface and the $\mathrm{scCO}_{2}$-treated surface contain trace amounts of aluminum. The aluminum from the galvanizing bath reacts with oxygen in air to form aluminum oxide $\left(\mathrm{Al}_{2} \mathrm{O}_{3}\right)$ on the surface of the HDG sheet [30]. Residual aluminum can also be detected after alkaline cleaning treatment [31]. The presence of aluminum in the $\mathrm{scCO}_{2}$ treated sample confirms the uneven surface coverage by the nanowire structure.

\subsection{FTIR Measurements}

The Fourier transform infrared spectroscopy (FTIR) spectrum of the zinc surface is presented in Figure 2. A broad absorption peak can be seen at $3260 \mathrm{~cm}^{-1}$ which refers to $\mathrm{OH}$ stretching vibration, indicating the presence of hydroxyl groups in the structure [32,33]. The presence of hydroxyl groups is supported by a small band at $1614 \mathrm{~cm}^{-1}$ which is attributed to interlayer $\mathrm{H}_{2} \mathrm{O}$ bending [34]. Intense double peak at $1516 \mathrm{~cm}^{-1}$ and $1380 \mathrm{~cm}^{-1}$ is an indication of antisymmetric $v_{3}$ stretching modes of carbonates [6,33]. This double peak is typical for zinc hydroxycarbonates containing both carbonate and hydroxyl groups, e.g., hydrozincite [35]. Peak at $1076 \mathrm{~cm}^{-1}$ is attributed to $v_{1}$ stretching of carbonates and is usually inactive in IR-measurements [33,35,36]. However, due to distortion-caused reduction in symmetry of the carbonate this band can become IR-active [33]. Further indication of carbonate presence is due to peaks $865 \mathrm{~cm}^{-1}, 835 \mathrm{~cm}^{-1}$ and $740 \mathrm{~cm}^{-1}$, which are attributed to carbonate bending modes of $v_{2}$, out-of-plane $v_{2}$ and $v_{4}$, respectively $[32,33,36]$. Hales et al. stated that the presence of multiple $v_{2}$ modes is also an indication of symmetry reduction of the carbonate anion, which coheres well with presence of the $1076 \mathrm{~cm}^{-1}$ peak. Finally, a small absorption peak at $465 \mathrm{~cm}^{-1}$ can be seen as well, which is an indication of some presence of zinc oxide [37,38]. Moreover, in a study where hydrozincite was synthesized from $\mathrm{ZnO}$, water and $\mathrm{CO}_{2}$, a similar peak can be found which was attributed to zinc oxide [39]. Since the nanowire structure does not cover the whole surface according to Figure $1 \mathrm{~b}$, it is likely that the presence of $\mathrm{ZnO}$ is measured from the sample surface rather than the nanowire structure.

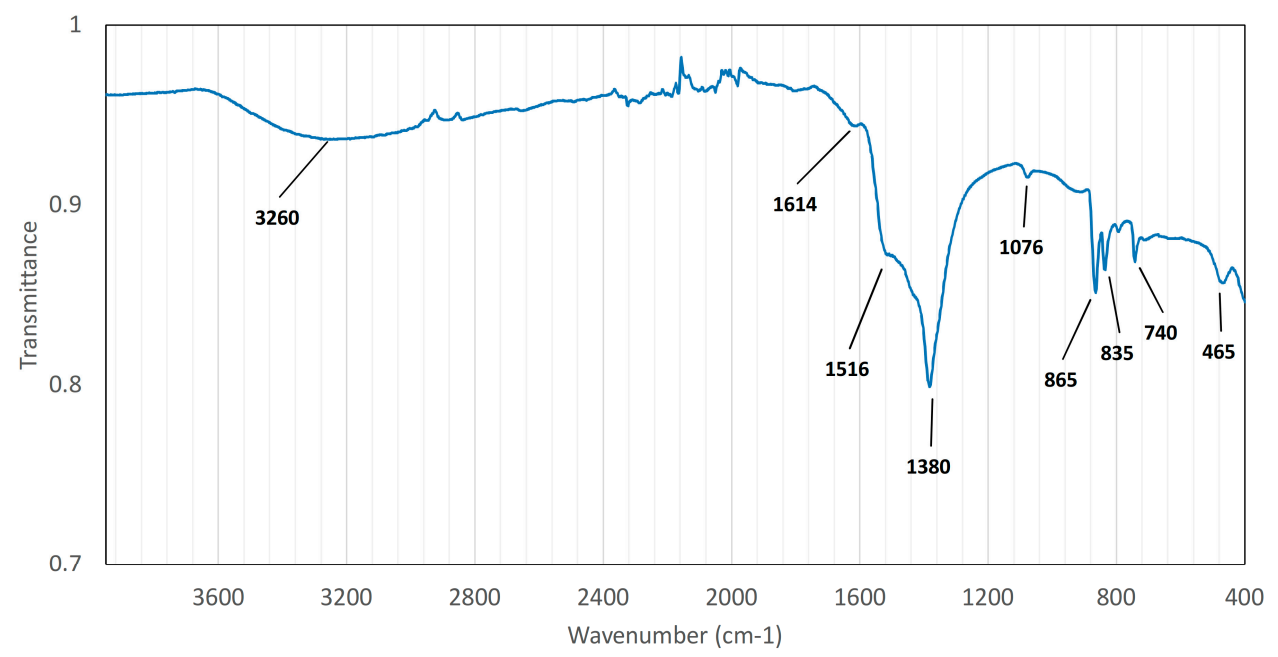

Figure 2. FTIR spectrum measured directly from the sample surface containing the nanowire structure.

\subsection{XPS Measurements}

The XPS survey spectrum of the nanowire-containing surface can be seen from Figure 3. Zinc presence can be seen from $\mathrm{Zn} 2 \mathrm{p}_{1 / 2}, \mathrm{Zn} 2 \mathrm{p}_{3 / 2}, \mathrm{Zn} 3 \mathrm{~s}$ and $\mathrm{Zn}$ LMM peaks. Clear indication of oxygen presence can be concluded from peaks $\mathrm{O} 1 \mathrm{~s}, \mathrm{O}$ KLL and carbon presence from peak $\mathrm{C}$ 1s. In addition, 
the surface contains also aluminum due to peaks $\mathrm{Al} 2 \mathrm{~s}$ and $\mathrm{Al} 2 \mathrm{p}$. These results are in good agreement with the EDS results.

The oxygen content was calculated from the X-ray photoelectron spectroscopy (XPS) data from three different points and it was on average 55.3 at \%. A minor $\mathrm{ZnO}$ presence can be concluded from the FTIR results as well as $\mathrm{Al}_{2} \mathrm{O}_{3}$ presence from the XPS results. However, it can be said that these alone cannot explain the high amount of oxygen on the surface. Therefore, it is expected that the origin of the measured oxygen is derived from the nanowire structure in a form of a zinc hydroxycarbonate.

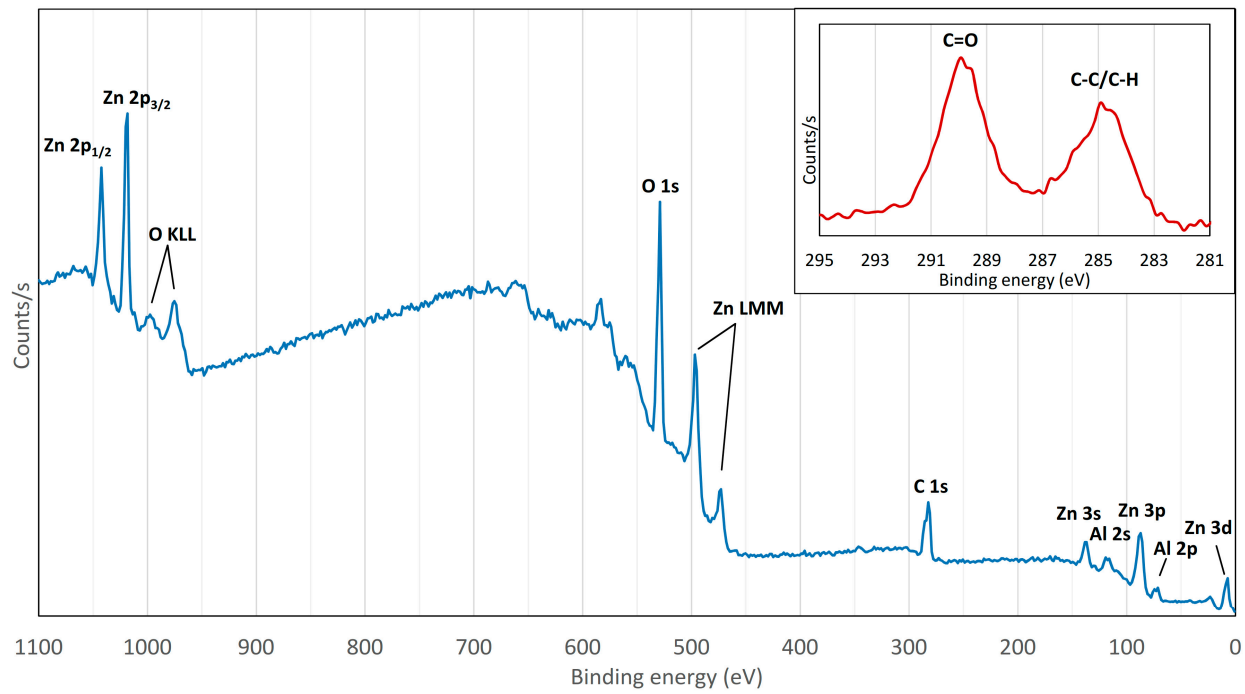

Figure 3. XPS survey spectrum of the $\mathrm{scCO}_{2}$-treated sample surface. The spectrum of the $\mathrm{C} 1 \mathrm{~s}$ peak is presented in the insert after the sample had gone through mild sputtering.

The insert in Figure 3 shows the $C$ 1s peak. The surface had gone through mild sputtering prior to the analysis in order to confirm that the detected carbon was not present solely as an impurity. We can see two separate peaks at $289.9 \mathrm{eV}$ and $285.0 \mathrm{eV}$. The latter peak is assigned to $\mathrm{C}-\mathrm{H}$ and $\mathrm{C}-\mathrm{C}$ bonding originating from adventitious carbon and, therefore, it is not part of the nanowire structure [31,40,41]. However, the peak at $289.9 \mathrm{eV}$ indicates the presence of carbonate groups in the structure. [31,41]. The peak position is typical for zinc hydroxycarbonates, which is in accordance with the FTIR results [9].

The FTIR and XPS results are in agreement that the nanowire structure contains both hydroxyl and carbonate groups, which agrees with zinc hydroxycarbonate substance. This is supported also by the EDS results. The FTIR spectrum fits well with hydrozincite, a type of zinc hydroxycarbonate, according to earlier studies [33,39]. However, Jambor et al. has stated that the FTIR spectrum is near identical for different zinc hydroxycarbonates exhibiting slightly different stoichiometric compositions [35]. Therefore, a more detailed analysis of the exact composition will be carried out in forthcoming studies.

All in all, the reaction in the $\mathrm{scCO}_{2}$ treatment involves $\mathrm{HDG}$ surface, $\mathrm{H}_{2} \mathrm{O}$ and $\mathrm{scCO}_{2}$. Zinc surface forms $\mathrm{ZnO}$ already in atmosphere by reacting with oxygen [42]. It is commonly known that $\mathrm{ZnO}$ acts as an intermediate reaction product for the formation of zinc hydroxycarbonates in atmospheric corrosion [1,33]. Moreover, $\mathrm{ZnO}$ has also been used as a starting material in hydrozincite powder synthesis together with $\mathrm{H}_{2} \mathrm{O}$ and pressurized $\mathrm{CO}_{2}$ [39]. $\mathrm{H}_{2} \mathrm{O}$ can react directly with zinc [1] or with $\mathrm{ZnO}$ [42] to produce $\mathrm{Zn}(\mathrm{OH})_{2}$. $\mathrm{Zn}(\mathrm{OH})_{2}$ is easily dissolved into $\mathrm{H}_{2} \mathrm{O}$ and so it can further react with $\mathrm{CO}_{2}$ to produce zinc hydroxycarbonates [42]. However, it has also been proposed that $\mathrm{Zn}(\mathrm{OH})_{2}$ can dehydrate back into $\mathrm{ZnO}$ and then react with $\mathrm{H}_{2} \mathrm{O}$ and $\mathrm{CO}_{2}$ to produce zinc hydroxycarbonates [1]. When $\mathrm{CO}_{2}$ dissolves into $\mathrm{H}_{2} \mathrm{O}$ it produces carbonic acid $\left(\mathrm{H}_{2} \mathrm{CO}_{3}\right)$ that dissociates into $\mathrm{HCO}_{3}{ }^{-}$and $\mathrm{CO}_{3}{ }^{2-}$ ions. The concentration of $\mathrm{HCO}_{3}{ }^{-}$is far greater than $\mathrm{CO}_{3}{ }^{2-}$ in the treatment conditions used, which is why $\mathrm{HCO}_{3}{ }^{-}$is more likely to be involved in the formation of the zinc hydroxycarbonate [28]. 
This is because $\mathrm{HCO}_{3}{ }^{-}$is unlikely to dissociate in acidic conditions due to its high $\mathrm{pK}_{\mathrm{a}}$ of over 10 [43]. Moreover, in earlier studies it has been concluded that the $\mathrm{HCO}_{3}{ }^{-}$ions are responsible for the zinc hydroxycarbonate formation [9,44]. To the best of our knowledge, formation of similar nanowire structures in atmospheric corrosion of zinc has not been reported in literature. Factors influencing the formation of the seemingly crystalline structure can be affected by much higher treatment pressure and $\mathrm{CO}_{2}$ concentration compared to atmospheric conditions. This is supported by earlier studies where partial pressure has been noticed to affect the formation of zinc corrosion products [33,45].

\section{Materials and Methods}

\subsection{Materials}

A rolled HDG steel sheet with a coating mass of $275 \mathrm{~g} \mathrm{Zn} / \mathrm{m}^{2}$ provided by SSAB Europe Oy was used as a substrate material. The zinc layer was $>99 \%$ pure with small amounts of alloying elements, e.g., aluminum. The sample dimensions were $25 \mathrm{~mm}$ width, $50 \mathrm{~mm}$ height and $0.5 \mathrm{~mm}$ thickness. The sample was cleaned using an alkaline treatment (Gardoclean 338, Chemetall, Frankfurt, Germany) to remove aluminum oxide layer from the outer surface. Only deionized water, with a conductivity of 2-10 $\mu \mathrm{S}$, and carbon dioxide ( $\geq 97 \%$, AGA, Espoo, Finland) were used for the $\mathrm{scCO}_{2}$ treatment.

\section{2. $\mathrm{ScCO}_{2}$ Apparatus and Sample Preparation}

The $\mathrm{scCO}_{2}$ treatments were performed using a Thar Technologies Inc. (Pittsburgh, PA, USA) RESS 250 system. The schematic of the system is presented in Figure 4. The $\mathrm{CO}_{2}$ flows initially from a siphon-tubed bottle. The $\mathrm{CO}_{2}$ is then cooled by a circulating cooling system to keep it in a liquid state so that it can be pumped into the reaction chamber by a PC-controlled high-pressure piston pump. Before the $\mathrm{CO}_{2}$ enters the reaction chamber, it is preheated to gaseous or supercritical state. The reaction chamber is made of $316 \mathrm{SS}$ steel and it has an internal heating system built into the walls. The co-solvent pump is used to pump co-solvents during experiments in high-pressures. The PC-controlled automatic back-pressure regulator (ABPR) controls the depressurization rate of the $\mathrm{CO}_{2}$ before it flows out from the top of the reaction chamber. Needle valves (V1 and V2) are used to control the pressure inside the system.

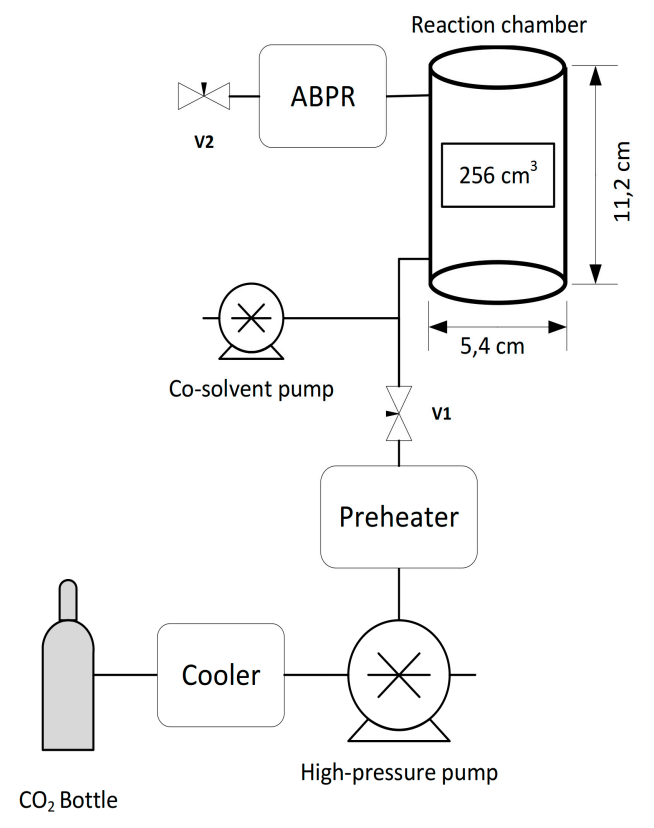

Figure 4. Schematic presentation of the $\mathrm{scCO}_{2}$ apparatus. 
The sample was prepared in the following manner. The HDG sheet was placed into the reaction chamber on a sample holder and the valve V2 was closed to ensure that no pressure drop occurred during the treatment. Then the chamber was closed and filled with $\mathrm{CO}_{2}$ after which it was heated to $50{ }^{\circ} \mathrm{C}$ and pressurized to 300 bar pressure. Valve V1 was then closed and $5 \mathrm{~mL}$ of deionized water was introduced to the chamber using the co-solvent pump. The duration of the treatment was $60 \mathrm{~min}$. When the treatment had finished, the valve V2 was opened and the reaction chamber was carefully depressurized of $\mathrm{CO}_{2}$ during 10 min using the ABPR.

\subsection{Characterization Tehcniques}

The sample surface was characterized with a field emission scanning electron microscope (FE-SEM, ZEISS ultra plus, Jena, Germany) with energy dispersive spectrometer (EDS, Oxford Instruments INCA Energy 350, Abingdon, UK) using a $15.0 \mathrm{kV}$ acceleration voltage. The EDS results were taken as average values from three separate points on the sample surfaces. FTIR (Bruker Tensor 27, Billerica, MA, USA) with attenuated total reflection (ATR) diamond sample holder and DLaTGS detector was used to analyse the composition of the nanowires in the spectral range of $3950-400 \mathrm{~cm}^{-1}$. The FTIR measurements were done directly from the sample surface. X-ray photoelectron spectroscope (XPS) (PHI Quantum 2000, Chanhassen, MN, USA) was used for the surface elemental analysis. A monochromated $\mathrm{Al} \mathrm{K \alpha}$ beam $(50 \mathrm{~W}, 15 \mathrm{kV})$ with a $200 \mu \mathrm{m}$ spot size was used to obtain the $\mathrm{C} 1 \mathrm{~s}$ spectrum. Mild sputtering of the sample surface was performed with $\mathrm{Ar}^{+}$ions. The $\mathrm{C}$ 1s peak at $285.0 \mathrm{eV}$ was used for the charge-shift correction.

\section{Conclusions}

A rapid formation of a nanowire structure was obtained on a HDG sheet using only supercritical carbon dioxide and water. The SEM imaging showed that the nanowires had a needle-like shape and they grew from distinct nucleation points on the surface into flower-like structures. The formation of the nanowires was due to a reaction between the zinc surface, water and carbon dioxide. According to the FTIR and XPS analysis, the nanowire structure consisted of hydroxyl and carbonate groups, which is also supported by the EDS results. Therefore, the nanowires are most likely a type of zinc hydroxycarbonate with a proposed stoichiometric formula of $\mathrm{Zn}_{x}\left(\mathrm{CO}_{3}\right)_{y}(\mathrm{OH})_{z}$. Determination of the exact composition as well as the reaction path remains a task for subsequent studies. The method presented in this study shows a great potential for its use as a pretreatment before coating to enhance the paint adhesion and electrochemical properties of the zinc/coating interface. Additionally, the nanowire structure may be used as starting material to produce a $\mathrm{ZnO}$ structure that could be used in high-end technological applications, e.g., sensors and dye-sensitized solar cells.

Acknowledgments: Digital, Internet, Materials \& Engineering Co-Creation (DIMECC) (formally FIMECC) and its HYBRIDS materials program is acknowledged for financial support. This work was also supported by an Academy of Finland project: Green processing of functional surface by supercritical carbon dioxide (decision number 304782).

Author Contributions: A.K. conceived and designed the experiments, carried out FTIR characterizations, and analyzed the data; V.S., A.M., P.V. contributed materials. V.S. performed XPS measurements; S.H. carried out SEM imaging; A.K., J.N. and E.L. designed the study; A.K. wrote the manuscript with critical output from all co-authors.

Conflicts of Interest: The authors declare no conflict of interest.

\section{References}

1. Zhang, X.G. Corrosion and Electrochemistry of Zinc; Springer: Boston, MA, USA, 1996; ISBN 978-1-4757-9879-1.

2. Puomi, P.; Fagerholm, H.M.; Rosenholm, J.B.; Jyrkäs, K. Comparison of different commercial pretreatment methods for hot-dip galvanized and Galfan coated steel. Surf. Coat. Technol. 1999, 115, 70-78. [CrossRef]

3. Cabanelas, I.; Collazo, A.; Izquierdo, M.; Nóvoa, X.R.; Pérez, C. Influence of galvanised surface state on the duplex systems behaviour. Corros. Sci. 2007, 49, 1816-1832. [CrossRef] 
4. Malone, J.F. Painting hot-dip galvanized sheet. Mater. Perform. 1992, 31, 39-42.

5. Collazo, A.; Pérez, C.; Izquierdo, M.; Merino, P. Evaluation of environmentally friendly paints over weathering galvanised steel. Prog. Org. Coat. 2003, 46, 197-210. [CrossRef]

6. Lindström, D.; Odnevall Wallinder, I. Long-term use of galvanized steel in external applications. Aspects of patina formation, zinc runoff, barrier properties of surface treatments, and coatings and environmental fate. Environ. Monit. Assess. 2011, 173, 139-153. [CrossRef]

7. Odnevall, I. A comparison between analytical methods for zinc specimens exposed in a rural atmosphere. J. Electrochem. Soc. 1991, 138, 1923-1928. [CrossRef]

8. Packham, D. Surface energy, surface topography and adhesion. Int. J. Adhes. Adhes. 2003, 23, 437-448. [CrossRef]

9. Miles, D.O.; Mattia, D. Hierarchical 3D ZnO nanowire structures via fast anodization of zinc. J. Mater. Chem. A 2015, 3, 17569-17577. [CrossRef]

10. $\mathrm{Hu}, \mathrm{Z}$.; Chen, Q.; Li, Z.; Yu, Y.; Peng, L.M. Large-scale and rapid synthesis of ultralong ZnO nanowire films via anodization. J. Phys. Chem. C 2010, 114, 881-889. [CrossRef]

11. Kołodziejczak-Radzimska, A.; Jesionowski, T. Zinc oxide-From synthesis to application: A review. Materials (Basel) 2014, 7, 2833-2881. [CrossRef]

12. Han, J.; Fan, F.; Xu, C.; Lin, S.; Wei, M.; Duan, X.; Wang, Z.L. ZnO nanotube-based dye-sensitized solar cell and its application in self-powered devices. Nanotechnology 2010, 21, 405203. [CrossRef] [PubMed]

13. Afifi, A.; Tabatabaei, M. Efficiency investigation of dye-sensitized solar cells based on the zinc oxide nanowires. Orient. J. Chem. 2014, 30, 155-160. [CrossRef]

14. Lin, C.-Y.; Lai, Y.-H.; Chen, H.-W.; Chen, J.-G.; Kung, C.-W.; Vittal, R.; Ho, K.-C. Highly efficient dye-sensitized solar cell with a ZnO nanosheet-based photoanode. Energy Environ. Sci. 2011, 4, 3448-3455. [CrossRef]

15. Khan, A.; Ali Abbasi, M.; Hussain, M.; Hussain Ibupoto, Z.; Wissting, J.; Nur, O.; Willander, M. Piezoelectric nanogenerator based on zinc oxide nanorods grown on textile cotton fabric. Appl. Phys. Lett. 2012, 101, 193506. [CrossRef]

16. Marie, M.; Mandal, S.; Manasreh, O. An electrochemical glucose sensor based on zinc oxide nanorods. Sensors 2015, 15, 18714-18723. [CrossRef] [PubMed]

17. Zhang, Y.; Yu, K.; Jiang, D.; Zhu, Z.; Geng, H.; Luo, L. Zinc oxide nanorod and nanowire for humidity sensor. Appl. Surf. Sci. 2005, 242, 212-217. [CrossRef]

18. Gao, Z.; Song, N.; Li, X. Microstructure design of hybrid CoO @ NiO and graphene nano-architectures for flexible high performance supercapacitors. J. Mater. Chem. A Mater. Energy Sustain. 2015, 3, 14833-14844. [CrossRef]

19. Bao, L.; Zang, J.; Li, X. Flexible $\mathrm{Zn}_{2} \mathrm{SnO}_{4} / \mathrm{MnO}_{2}$ Core/Shell nanocable? Carbon microfiber hybrid composites for high-performance supercapacitor electrodes. Nano Lett. 2011, 11, 1215-1220. [CrossRef] [PubMed]

20. Gao, Z.; Yang, W.; Wang, J.; Song, N.; Li, X. Flexible all-solid-state hierarchical $\mathrm{NiCo}_{2} \mathrm{O}_{4} /$ porous graphene paper asymmetric supercapacitors with an exceptional combination of electrochemical properties. Nano Energy 2015, 13, 306-317. [CrossRef]

21. Gao, Z.; Bumgardner, C.; Song, N.; Zhang, Y.; Li, J.; Li, X. Cotton-textile-enabled flexible self-sustaining power packs via roll-to-roll fabrication. Nat. Commun. 2016, 7, 1-12. [CrossRef] [PubMed]

22. Gao, Z.; Song, N.; Zhang, Y.; Li, X. Cotton textile enabled, all-solid-state flexible supercapacitors. RSC Adv. 2015, 5, 15438-15447. [CrossRef]

23. Zhang, Y.; Gao, Z.; Song, N.; Li, X. High-performance supercapacitors and batteries derived from activated banana-peel with porous structures. Electrochim. Acta 2016, 222, 1257-1266. [CrossRef]

24. Cansell, F.; Aymonier, C. Design of functional nanostructured materials using supercritical fluids. J. Supercrit. Fluids 2009, 47, 508-516. [CrossRef]

25. Wang, K.; Wei, M.; Morris, M.A.; Zhou, H.; Holmes, J.D. Mesoporous titania nanotubes: Their preparation and application as electrode materials for rechargeable lithium batteries. Adv. Mater. 2007, 19, 3016-3020. [CrossRef]

26. Zhang, X.; Heinonen, S.; Levänen, E. Applications of supercritical carbon dioxide in materials processing and synthesis. RSC Adv. 2014, 4, 61137-61152. [CrossRef]

27. Sanli, D.; Bozbag, S.E.; Erkey, C. Synthesis of nanostructured materials using supercritical $\mathrm{CO}_{2}$ : Part I. Physical transformations. J. Mater. Sci. 2012, 47, 2995-3025. [CrossRef] 
28. Choi, Y.S.; Nešić, S. Determining the corrosive potential of $\mathrm{CO}_{2}$ transport pipeline in high $\mathrm{pCO}$-water environments. Int. J. Greenh. Gas Control 2011, 5, 788-797. [CrossRef]

29. Cole, I.S.; Paterson, D.A.; Corrigan, P.; Sim, S.; Birbilis, N. State of the aqueous phase in liquid and supercritical $\mathrm{CO}_{2}$ as relevant to CCS pipelines. Int. J. Greenh. Gas Control 2012, 7, 82-88. [CrossRef]

30. Biber, H.E. Scanning auger microprobe study of hot-dipped regular-spangle galvanized steel: Part I. Surface composition of As-produced sheet. Metall. Trans. A 1988, 19, 1603-1608. [CrossRef]

31. Berger, R.; Bexell, U.; Stavlid, N.; Grehk, T.M. The influence of alkali-degreasing on the chemical composition of hot-dip galvanized steel surfaces. Surf. Interface Anal. 2006, 38, 1130-1138. [CrossRef]

32. Su, B.; Li, M.; Shi, Z.; Lu, Q. From superhydrophilic to superhydrophobic: Controlling wettability of hydroxide zinc carbonate film on zinc plates. Langmuir 2009, 25, 3640-3645. [CrossRef] [PubMed]

33. Hales, M.C.; Frost, R.L. Synthesis and vibrational spectroscopic characterisation of synthetic hydrozincite and smithsonite. Polyhedron 2007, 26, 4955-4962. [CrossRef]

34. Zahra, F.; Khalidi, A.; Abdennouri, M. Zn-Al layered double hydroxides intercalated with carbonate, nitrate, chloride and sulphate ions: Synthesis, characterisation and dye removal properties. Integr. Med. Res. 2016, 11, 90-100. [CrossRef]

35. Jambor, J.L. Studies of basic copper and zinc Carbonates: I-synthetic zinc carbonates and their relationship to hydrozincite. Can. Mineral. 1964, 8, 92-108.

36. Cheng, J.; Poduska, K. A strategy for hydroxide exclusion in nanocrystalline solid-state metathesis products. Nanomaterials 2013, 3, 317-324. [CrossRef] [PubMed]

37. Hong, R.Y.; Li, J.H.; Chen, L.L.; Liu, D.Q.; Li, H.Z.; Zheng, Y.; Ding, J. Synthesis, surface modification and photocatalytic property of ZnO nanoparticles. Powder Technol. 2009, 189, 426-432. [CrossRef]

38. Zhang, X.; Liu, X.; Odnevall Wallinder, I.; Leygraf, C. The protective role of hydrozincite during initial corrosion of a Cu40Zn alloy in chloride-containing laboratory atmosphere. Corros. Sci. 2015, 103, $20-29$. [CrossRef]

39. Turianicová, E.; Káňuchová, M.; Zorkovská, A.; Holub, M.; Bujnáková, Z.; Dutková, E.; Baláz, M.; Findoráková, L.; Balintová, M.; Obut, A. $\mathrm{CO}_{2}$ utilization for fast preparation of nanocrystalline hydrozincite. J. $\mathrm{CO}_{2}$ Util. 2016, 16, 328-335. [CrossRef]

40. Diler, E.; Lescop, B.; Rioual, S.; Nguyen Vien, G.; Thierry, D.; Rouvellou, B. Initial formation of corrosion products on pure zinc and $\mathrm{MgZn}_{2}$ examinated by XPS. Corros. Sci. 2014, 79, 83-88. [CrossRef]

41. Ballerini, G.; Ogle, K.; Barthés-Labrousse, M.G. The acid-base properties of the surface of native zinc oxide layers: An XPS study of adsorption of 1,2-diaminoethane. Appl. Surf. Sci. 2007, 253, 6860-6867. [CrossRef]

42. Graedel, T.E. Corrosion mechanisms for zinc exposed to the atmosphere. J. Electrochem. Soc. 1989, 136, 193C-203C. [CrossRef]

43. Hastings, B.; Sendroy, J. The effect of variation in ionic strength on the apparent first and second dissociation constants of carbonic acid. J. Biol. Chem. 1925, 65, 445-455.

44. O'Connor, M.F. A study of the kinetics of the basic zinc carbonate formation reaction. Z. Natursforsch B 1975, 30, 665-668. [CrossRef]

45. Falk, T.; Svensson, J.-E.; Johansson, L.-G. The role of carbon dioxide in the atmospheric corrosion of zinc. J. Electrochem. Soc. 1998, 145, 39-44. [CrossRef]

(C) 2017 by the authors. Licensee MDPI, Basel, Switzerland. This article is an open access article distributed under the terms and conditions of the Creative Commons Attribution (CC BY) license (http://creativecommons.org/licenses/by/4.0/). 